\title{
Editorial RES 3/2017
}

As part of the 500th anniversary of the Reformation, the Institute for Ecumenical Research organized a symposium entitled Reformation and Orthodoxy in May this year. The articles of the current issue of RES are the papers which were presented at the symposium and which met the academic criteria for their inclusion in our journal.

The connections between the Reformation and the Orthodox churches have a long tradition. Melanchthon himself tried to contact the Ecumenical Patriarch Joasaph II (1555-1565). The letter exchange between Tübingen theologians and Patriarch Jeremias II (1573-1581) was particularly rich in content. The Anglican Church was in dialogue with Patriarch Kyrill Lukaris $(\dagger 1638)$.

The first two contributions (by Daniel Benga and Mugurel Păvălucă) convey an Orthodox perspective over the Reformation concepts of Martin Luther by clarifying the issue of how Luther referred to Christian Orthodoxy. Benga emphasizes that there is no comprehensive analysis of Luther's thinking in Eastern theology; the focus has very much been on the question of the innovations in doctrine and too little attention has been paid to the concern of the renewal of ecclesial life.
Im Rahmen der 500-Jahr-Feier der Reformation hat das Institut für Ökumenische Forschung im Mai dieses Jahres ein Symposium mit dem Titel Reformation und Orthodoxie veranstaltet. Die Aufsätze der vorliegenden Nummer von RES gehen darauf zurück; es wurden diejenigen Beiträge ausgewählt, die den Kriterien zur Aufnahme in unsere Zeitschrift entsprachen.

Die Beziehungen zwischen der Reformation und den Orthodoxen Kirchen hat eine lange Tradition. Bereits Melanchthon suchte den Kontakt mit dem Ökumenischen Patriarchen Joasaph II (1555-1565). Besonders inhaltsreich war der Briefwechsel der Tübinger Theologen mit dem Patriarchen Jeremias II (15731581). Die Anglikanische Kirche führte einen Dialog mit dem Patriarchen Kyrill Lukaris († 1638).

Die ersten beiden Beiträge (von Daniel Benga und Mugurel Păvălucă) geben eine orthodoxe Sicht auf die reformatorischen Gedanken Martin Luthers wieder, beziehungsweise beleuchten die Frage, in welcher Weise sich Luther auf die Orthodoxie bezogen hatte. Benga betont, dass es in der östlichen Theologie noch keine zusammenhängende Analyse von Luthers Denken gibt; man hatte sich auf die Frage nach den Neuerungen in der Lehre konzentriert und das An- 
Păvălucă, for his part, describes Luther's sporadic and not very consistent remarks on Christian Orthodoxy. These two contributions are complementary and provide a good starting point for understanding some aspects of the current ecumenical dialogue between Protestantism and Orthodoxy.

From the Orthodox point of view, Maria Curtean approaches Luther's interpretation of the Magnificat (Lk $1,46 \mathrm{~b}-55)$. Her analysis is original and inspiring as she emphasizes the importance of this Lutheran writing as the source for the Christian education of statesmen, and therefore considers it as part of the universal Christian heritage.

An interesting retrospective of the 450th anniversary of the Reformation is provided by Dragos Boicu. $\mathrm{He}$ analyses the Orthodox statements that were made in Romania at the time of the anniversary and particularly highlights the non-theological and political factors. The situation behind the Iron Curtain explains the rather stiff language and the occasional anti-Western remarks in the examined sources.

Constantin Necula addresses the work of Dietrich Bonhoeffer and shows how this could be significant for contemporary Orthodox homiletics. The sermon, he emphasizes, is the testimony of the experience of the Church, and this applies to the same extent to Western and Eastern theology. liegen der Erneuerung des kirchlichen Lebens zu wenig beachtet. Păvălucă seinerseits beschreibt die sporadischen und nicht sehr konsequenten Bemerkungen Luthers zur Orthodoxie. Diese beiden Aufsätze sind komplementär und bilden einen guten Ausgangspunkt, um den aktuellen ökumenischen Dialog zwischen Protestantismus und Orthodoxie zu verstehen.

Maria Curtean nähert sich aus orthodoxer Sicht Luthers Auslegung des Magnifikat (Lk 1,46b-55). Ihre Analyse ist deshalb orginell und anregend, weil sie die Bedeutung dieser Lutherschrift als Quelle christlicher Erziehung von Staatsmännern herausstreicht und sie darum als Teil des universellen christlichen Erbes betrachtet.

Einen interessanten Rückblick auf die 450-Jahr-Feier der Reformation bietet der Beitrag von Dragoș Boicu. Er analysiert die damaligen orthodoxen Stellungnahmen in Rumänien und zeigt besonders die nicht-theologischen, politischen Faktoren auf. Die Situation hinter dem Eisernen Vorhang erklärt die eher steife Sprache und die gelegentlichen antiwestlichen Auslassungen.

Constantin Necula greift das Werk von Dietrich Bonhoeffer auf und zeigt, inwiefern dieses für die gegenwärtige orthodoxe Homiletik bedeutsam sein könnte. Die Predigt so streicht er heraus - ist das Zeugnis der Erfahrung der Kirche, und dies gilt gleichermaßen für westliche wir für östliche Theologie. 
Daniel Mihoc offers a Biblical study: he describes the question of salvation in the Revelation of John and the polemics that unfolded between Protestant and Orthodox exegesis. A clarification of the concepts is an important step so that one may grasp, beyond the differences of interpretation, the similarities as well.

Finally, in the category dedicated to essays, one may find a contribution by Christoph Klein. He describes the varied interactions of the Transylvanian reformer Johannes Honterus with Orthodoxy and the ensuing mutual influences as a form of 'early ecumenism'.

This latter contribution is thus relevant also in respect to this region, in which different forms of the Reformation not only share geographical space, but also look back on a long common history, with Catholicism and Orthodoxy. We hope that with this issue of RES - which, exceptionally, is made up by authors from Romania alone - we will contribute to an ecumenical ethos that is essential for the next steps of the dialogue.
Eine biblische Studie bietet Daniel Mihoc: er beschreibt die Frage nach der Erlösung in der Offenbarung des Johannes und die Polemik, die sich zwischen protestantischer und orthodoxer Exegese diesbezüglich entfaltet hatte. Eine Klärung der Begriffe ist ein wichtiger Schritt, um jenseits der Differenzen auch die Ähnlichkeiten in den Blick zu bekommen.

In der Rubrik der Essays findet sich schließlich ein Beitrag von Christoph Klein. Er beschreibt die vielfältigen Beziehungen des siebenbürgischen Reformators Johannes Honterus mit der Orthodoxie und die gegenseitigen Einflüsse als eine Form der ,frühen Ökumene'.

Dieser letztgenannte Beitrag ist somit zugleich bezeichnend für diese Region, in der verschiedene Ausprägungen der Reformation mit dem Katholizismus und der Orthodoxie nicht nur den geographischen Raum teilen, sondern auch auf eine lange gemeinsame Geschichte zurückblicken. Wir hoffen, mit dieser Nummer von RES - die ausnahmsweise nur von Autoren aus Rumänien gefüllt wurde - einen Beitrag an ein ökumenisches Ethos zu leisten, das für den weiteren Weg des Dialogs wesentlich ist.

Guest editor Ciprian Toroczkai 